\title{
GLASS RECYCLING IN SRI LANKA: A FINANCIAL ANALYSIS
}

\author{
N.W.K.P.S. Nanayakkara and U. A. D. P. Gunawardena \\ Department of Forestry and Environmental Science, University of Sri Jayewardenepura \\ Email: piyumisir@yahoo.com, Tel: +9477660 0358
}

\begin{abstract}
Glass recycling is the use of secondary raw materials or post consumer glass waste for the manufacturing of new or similar products. Glass Company of Sri Lanka is manufacturing glass containers and also involved in glass container recycling in Sri Lanka. The main purpose of the study is to carry out a financial analysis of glass recycling from company point of view along with an analysis on possible best practices that could enhance the recycling behaviours of individuals. The primary data was gathered from a household questionnaire survey which was conducted in Western Province of Sri Lanka. Sample of 150 households were selected from 8 GN divisions in Colombo, Gampaha and Kaluthara districts representing two Municipal councils, three urban councils, and three Pradeshiya Sabha. Six different scenarios were proposed for the respondents in order to generate information on practices that are most preferred by them and on their willing levels of recycling under each scenario. Results revealed that the best scenario was the introduction of door to door collectors which yielded highest net present value of Rs. Mn $1,517.39$ at $10 \%$ discount rate and resulted $7.98 \%$ of net profit increase from the current glass recycling process of Glass Company.
\end{abstract}

Keywords: glass recycling, financial analysis

\section{INTRODUCTION}

Glass is one of the important commodities in Sri Lanka. Total glass imported to Sri Lanka is 60,547.93 tons and the total glass exported from Sri Lanka is 53,372.97 tons in year 2009 (Sri Lanka customs, 2009).

Glass recycling is one of the best waste management practices that use glass waste for the manufacture of new or similar product (Wen et al., 2009; Agarwal, 2008). Basically two major processes are involved in evolution of recycling in the world. The rising costs of virgin raw materials and of waste disposal increase the attractiveness of recycling. Glass manufacturing needs input of virgin raw materials such as silica sand, feldspar, dolomite, etc considered as non renewable mineral resources. At the same time, the costs of disposing of the products would probably rise as population density became more pronounced and wealth levels supported higher levels of waste. As a result, while market mechanisms automatically create pressures for recycling and reuse that are generally in the right direction, they are not always of the correct intensity. Higher disposal costs and increasing scarcity of virgin materials do create a larger demand for recycling (Tietenberg \& Lewis, 2009).

Glass recovery is important to carryout or increase glass recycling process. The first step of the recovery process is the differentiated collection of used products that is of the empty containers, which therefore become potential raw materials instead of waste (Vellini \& Savioli, 2008). Both formal and informal sectors are important for the country to enhance recycling processes. A hierarchy of recyclable dealers (small, medium and large) plays an important role in the solid waste management. (Agarwal et al., 2004 ;Haan et al., 1998; Wilson et al., 2008). The public support is vital to success of most recycling schemes (Wilson \& Williams, 2007). Usually public consume different products which packaged inside glass

Proceedings of the 15 ${ }^{\text {th }}$ International Forestry and Environment Symposium, 26-27 November 2010.

Published by Department of Forestry and Environmental Science, University of Sri Jayewardenepura, Sri Lanka. 
bottles or jars. Post consumer glass container waste needed to reuse or recycle in order to reduce waste generation.

According to the database of Municipal Solid Waste collection in Sri Lanka (2005), glass wastes consisted of $2.03 \%$ from total solid waste collection in Sri Lanka. Ceylon Glass Company uses about $40 \%$ of recycled glass (cullet) in the glass manufacturing process. Glass recycling in Sri Lanka involves the use of scraps or wasted glass containers in flint and amber colour for the manufacturing of new glass containers. Glass Company of Sri Lanka manufactures glass containers and company also has the technology of wasted glass recycling. Indirectly recycling offers benefits for the recycling industries such as cost reduction of raw materials and energy, increase lifetime of machineries and build up company image among public. Glass recycling is better for the environment through reducing air emissions and waste generation. Directly public will get benefits such as monetary returns for their wasted glass, overcome problems such as spread of diseases such as dengue, injuries due to glass scraps and etc. Therefore glass recycling contributes to win - win situation for all parties in the society.

In order to optimize the economic and environmental benefits of glass recycling, maximum collection of wasted glass are required. Presently Glass Company has introduced certain practices such as target schemes and transport fee for major glass collectors and providing publicity through paper advertisements, brochures etc. However, the present glass collection system is not functioning at optimal capacity and improvements in the glass recycling could bring significant benefits to the company in terms of energy and raw material savings.

An in depth analysis however is lacking with regard to possible improvements of the existing system. The present study is focused to figure out further possible improvements for glass recycling sector a research on economics of glass recycling would provide many insights to the glass recycling, while boosting the recovery of glass in different ways to achieve to the optimal level of glass recycling in Sri Lanka.

The main purpose of the study is therefore to carry out a financial analysis of glass recycling from Glass company point of view with possible best practices that could enhance the recycling behaviours of individuals. Several scenarios to improve glass recycling process were formulated including (a) increasing the prices paid by Glass company for collected glass, (b) public awareness creation to enhance sorting of glass waste, reuse and recycling, (c) providing bags to separate glass waste, (d) introducing door to door collection systems and (e) establishing collection centers to improve recycling.

\section{METHODOLOGY}

The study adopted basic framework of cost benefit analysis. The basic methodology involves identification and measurement of costs and benefits in monetary terms for inclusion in the formal project analysis.

\subsection{DEVELOPMENT OF DIFFERENT SCENARIOS WHICH INFLUENCE GLASS RECYCLING PROCESS OF GLASS COMPANY}

Possible practices or programs performed by either individuals or institutes were identified which can improve the recycling process of Glass Company. These practices were identified through secondary data collected from Glass Company, government institutes who are involved in glass waste management in Sri Lanka such as Central Environmental Authority (CEA), Waste Management Authority - Western

Proceedings of the 15 ${ }^{\text {th }}$ International Forestry and Environment Symposium, 26-27 November 2010.

Published by Department of Forestry and Environmental Science, University of Sri Jayewardenepura, Sri Lanka. 
Province, local authorities, etc and from previous research conducted on glass recycling in different countries.

Based on these practices, different scenarios were developed. Main purpose of development of such scenarios is the improving of recycling behaviours of households while providing better encouragement for their recycling activities. Different scenarios that proposed for the study are given below,

Scenario 1: Increasing the price paid by Glass Company for $1 \mathrm{~kg}$ of collected glass

Scenario 2: Introducing door to door collectors

Scenario 3: Establishing collection centers

Scenario 4: Providing bins for dumping waste

Scenario 5: Providing bags for sorting waste

Scenario 6: Public awareness creation

\subsection{PRIMARY AND SECONDARY DATA COLLECTION}

Householders are considered as the final consumer of glass container products and majority of post consumer glass waste generated from households. According to Glass Company, majority of glass collection is from households and it is approximately $76 \%$ including door to door, other and regular

container waste collection from households. Therefore a household survey was designed in primary data collection related to households including socio economic data, glass container product consumption, their willingness for the different proposed scenarios etc.

high population over other provinces. Sample of 150 households were selected from 8 GN divisions in Colombo, Gampaha and Kaluthara districts representing two Municipal councils, three urban councils, and three Pradeshiya Sabha based on estimated mid year population (Table 2.1).

The information on glass recycling was gathered mainly from the Glass Company through personnel interviews which included general information including history of Glass Company, glass container manufacturing and recycling processes, primary and secondary raw materials used for glass container manufacturing and advantages of glass recycling etc.

A small survey was conducted in selected glass container purchasing industries of Glass Company (Company survey) and the supermarket for further secondary data collection on reusable bottles and their deposit refunds.

Proceedings of the 15 ${ }^{\text {th }}$ International Forestry and Environment Symposium, 26-27 November 2010.

Published by Department of Forestry and Environmental Science, University of Sri Jayewardenepura, Sri Lanka. 
Table 2.1: Selected number of households from each LA

\begin{tabular}{llccc}
\hline District & Selected LA & Population & $\begin{array}{c}\text { Required No. of } \\
\text { HH from each LA }\end{array}$ & Selected GN division \\
\hline Colombo & Colombo MC & 642,020 & 39 & Nawagampura \\
& Maharagama UC & 180,112 & 11 & Godigamuwa South \\
& Kaduwela PS & 187,000 & 11 & Thalahena North B \\
Gampaha & Gampaha MC & 57,429 & $\mathbf{6 1}$ & Aluthgama North \\
& Peliyagoda UC & 29,880 & 17 & Pattiya East \\
& Kelaniya PS & 104,708 & 9 & Egoda Eriyawetiya \\
& & Sub total & 32 & Kankanamgoda \\
Kaluthara & Beruwala UC & 33,474 & 7 & Payagala North \\
& Beruwala PS & 111,198 & 24 & \\
\hline Total & & Sub total & $\mathbf{3 1}$ & \\
\hline
\end{tabular}

Table 2.2: Local companies selected for the survey

\begin{tabular}{ll}
\hline Product category & \multicolumn{1}{c}{ Selected Company } \\
\hline Food \& Beverages & MD Lanka Canneries Ltd \\
Beer & Lion Brewery Ceylon PLC \\
Aerated Drinks & Cocacola Beverages SL Ltd \\
Pharmaceuticals & J L Morrison Son \& Jones (Ceylon) PLC \\
Agrochemicals & Lankem Ceylon PLC \\
Cosmetics \& Perfumes & Hemas Cosmetics (Pvt) Ltd \\
\hline
\end{tabular}

(Source: Glass Company, 2009)

Proceedings of the 15 $5^{\text {th }}$ International Forestry and Environment Symposium, 26-27 November 2010.

Published by Department of Forestry and Environmental Science, University of Sri Jayewardenepura, Sri Lanka. 


\subsection{COSTS AND REVENUES OF CURRENT PROCESS OF GLASS COMPANY IN SRI LANKA}

The basic costs associated with glass manufacturing and recycling processes were gathered; cost of raw materials, cost of energy, cost of salaries and wages, cost of depreciation and other overhead. Sale of glass containers to local market and export market are the basic revenues of Glass Company.

The following table gives details of estimation of individual cost and benefit items.

Table 2.3: Details of the data collected

\begin{tabular}{ll}
\hline Data type & Details of the data collected \\
\hline Cost items & $\begin{array}{l}\text { Annual requirement of primary and secondary raw materials and } \\
\text { their market values. } \\
\text { Annual requirement of energy types including LPG, furnace oil } \\
\text { and electricity and their market values. } \\
\text { Energy }\end{array}$ \\
$\begin{array}{l}\text { Annual salaries and wages paid for the workers of the company. } \\
\text { Thiaries and wages }\end{array}$ & $\begin{array}{l}\text { This value has been obtained from Glass Company. } \\
\text { Thepreciation }\end{array}$ \\
$\begin{array}{l}\text { Other overhead } \\
\text { Revenue items }\end{array}$ & $\begin{array}{l}\text { Annual revenue from local sale of glass containers } \\
\text { Annual revenue from export sale of glass containers }\end{array}$ \\
\hline
\end{tabular}

Glass manufacturing is a continuous process which operates for 24 hours and present Glass company production is $230 \mathrm{mtd}$ which can be maximized up to $250 \mathrm{mtd}$. It is assumed that only flint and amber glass containers are manufactured throughout the year due to lack of information regarding Green or other colour batches and the manufacturing of green and other colour batches are carried out only for customer requirements.

Cost of raw materials consisted of two categories of costs, i.e. cost of batch which includes the cost of virgin raw materials or primary raw materials and the cost of cullet or scrap glass. Glass Company uses Liquefied Petroleum Gas (LPG), furnace oil and electricity as main sources of energy. With the input of cullet, the requirement of energy, mainly furnace oil and LPG usage is reduced. However the electricity consumption is not affected with the increase of cullet, because electricity is used only for startup of machineries. Energy consumption of cullet will result in a $2.5 \%$ reduction in the required melting energy for every additional $10 \%$ of cullet (Krivtsov et al., 2004).

Both depreciation and other overhead values are usually being estimated by Glass Company for a year. Glass Company considered those as confidential and it is assumed that these values are constant per yr.

Basic revenue generated through selling of glass containers to local companies and export market were collected from Glass Company.

Proceedings of the $15^{\text {th }}$ International Forestry and Environment Symposium, 26-27 November 2010.

Published by Department of Forestry and Environmental Science, University of Sri Jayewardenepura, Sri Lanka. 
A Financial analysis for Glass Company was carried out using collected cost and revenue data of Glass Company for year 2009. Several criteria can be used to determine the financial viability of Glass Company under different situations and the criteria such as net present value and benefit cost ratio were used in this study. Net present values were calculated using discount rates of 5\%, $10 \%$ and $12 \%$ for present process and different scenarios.

\subsection{COSTS AND REVENUES OF DIFFERENT PROPOSED SCENARIOS OF GLASS COMPANY IN SRI LANKA}

The annual additional quantities of glass to be collected under different scenarios in Western Province were estimated using primary and secondary data collection. Summation of these obtained additional quantities and the quantity of glass collected at present situation provided the total quantity of glass to be collected under different scenarios. These additional quantities will result in higher recycling rates than present glass recycling process of the Glass Company.

\section{RESULTS}

\subsection{FINANCIAL ANALYSIS FOR CURRENT RECYCLING AND DIFFERENT PROPOSED SCENARIO PROCESSES OF GLASS COMPANY IN SRI LANKA}

This section provides the results of financial analysis carried out for Glass Company at current situation and under identified scenarios which influence Glass Company recycling process.

After extrapolation, the total additional cullet collection per year from Western Province was calculated and given in the following table.

Table 3.1: Additional quantity of glass to be collected per year under different scenarios in Western Province

\begin{tabular}{crr}
\hline Scenario & $\begin{array}{r}\text { Flint cullet } \\
\text { (tons/yr) }\end{array}$ & $\begin{array}{r}\text { Amber cullet } \\
\text { (tons/yr) }\end{array}$ \\
\hline 01 & $1,638.90$ & 904.75 \\
02 & $5,208.12$ & $2,784.99$ \\
03 & $4,254.32$ & $2,348.26$ \\
04 & $5,032.53$ & $2,613.59$ \\
05 & $4,560.29$ & $1,921.23$ \\
06 & $4,392.19$ & $2,403.07$ \\
\hline
\end{tabular}

\subsection{ESTIMATION THE COSTS AND REVENUES}

This section describes the estimation of costs and revenues of Glass Company under different scenarios. As an example the estimation of costs and revenues under scenario 1 is given as follows.

Proceedings of the $15^{\text {th }}$ International Forestry and Environment Symposium, 26-27 November 2010.

Published by Department of Forestry and Environmental Science, University of Sri Jayewardenepura, Sri Lanka. 


\section{Estimation the costs and revenues of scenario 1}

\section{C1 - Cost of raw materials}

\begin{tabular}{llrrrr}
\hline \multirow{2}{*}{ Scenario } & Description & \multicolumn{3}{c}{ NPV } & \multirow{2}{*}{ BCR } \\
\cline { 3 - 4 } & & $\mathbf{5 \%}$ & $\mathbf{1 0 \%}$ & $\mathbf{1 2 \%}$ & \\
\cline { 3 - 4 } Current & $\begin{array}{l}\text { Current glass recycling process } \\
\text { of Glass Company }\end{array}$ & $2,108.85$ & $1,405.18$ & $1,255.24$ & 1.1821 \\
Scenario 1 & $\begin{array}{l}\text { Increasing the price paid for } \\
\text { collected glass }\end{array}$ & $1,635.35$ & $1,089.68$ & 973.40 & 1.1356 \\
Scenario 2 & $\begin{array}{l}\text { Introducing door to door } \\
\text { collectors }\end{array}$ & $2,277.25$ & $1,517.39$ & $1,355.47$ & 1.1995 \\
Scenario 3 & Establishing collection centers & $2,257.01$ & $1,503.91$ & $1,343.43$ & 1.1974 \\
Scenario 4 & $\begin{array}{l}\text { Providing bins for dumping } \\
\text { waste }\end{array}$ & $2,274.97$ & $1,515.87$ & $1,354.11$ & 1.1993 \\
Scenario 5 & Providing bags for sorting waste & $2,272.63$ & $1,514.32$ & $1,352.73$ & 1.1990 \\
Scenario 6 & Public awareness creation & $2,259.99$ & $1,505.89$ & $1,345.20$ & 1.1977 \\
\hline
\end{tabular}

Table 3.2: Results of financial analysis

The quantity of flint cullet increase due to scenario 1 was 1,638.90 tons per year. Therefore total expected quantity of flint cullet collection per year is 20,422.35 tons $(18,783.45+1,638.90)$. Expected average price of $1 \mathrm{~kg}$ of flint cullet is Rs. 9.91. With the increase of flint cullet quantities the requirement of virgin raw material quantity decreases and it also reduces number of flint batches to 103 .

The quantity of amber cullet increase due to scenario 1 was 904.75 tons per year as given in Table 4.10. Therefore total expected quantity of flint cullet collection per year is 4,662.39 tons $(3,757.64+904.75)$. Expected average price of $1 \mathrm{~kg}$ of amber cullet is Rs. 6.87. With the increase of amber cullet quantities the requirement of virgin raw material amount decreases and it is reduces number of amber batches to 78 .

\section{C2 - Cost of energy}

Due to increase of Cullet collection by different scenarios, energy consumption for glass container manufacturing will be reduced than the present process. Depending on the cullet collection the energy cost can be calculated.

Other costs involved in Glass manufacturing such as salaries and wages, depreciation and other overhead were calculated.

Basic revenue is generated through selling of glass containers to local companies and export market. The the bottles sold to the local market and export market is constant.

Proceedings of the $15^{\text {th }}$ International Forestry and Environment Symposium, 26-27 November 2010.

Published by Department of Forestry and Environmental Science, University of Sri Jayewardenepura, Sri Lanka. 
Estimation of costs and revenues of scenario 2, 3, 4, 5 and 6 have followed the same procedure as mentioned for scenario 1 . Table 4.12 denotes the required quantities, total costs of primary and secondary raw materials, energy types and labourers for the scenario 1, 2, 3, 4, 5 and 6.

Results revealed that the best scenario was the introduction of door to door collectors which yielded highest net present value of Rs. Mn 1,517.39 at 10\% discount rate. This yielded 7.98\% increase from the current glass recycling process of Glass Company (Table 3.2).

\section{DISCUSSION}

When performing financial analysis, several limitations have to be faced. The following section describes the limitations.

Since the financial analysis was conducted for each scenario, all costs and revenues of the entire scenarios had to be estimated. There were several limitations from Glass Company point of view, in estimation of optimal recycling rates that can be obtained from different scenarios. According to the Glass Company, the maximum flint recycling rate that can be achieved was $75 \%$ and the maximum amber recycling rate was $90 \%$. Majority of scenarios yielded higher amber glass collection per year than the required maximum rate. Therefore it is suggested that additional amber glass collection can be stored within factory premises for future usage or Glass Company can go for further technical changes where the cullet can be utilized at a theoretically maximum point of $100 \%$. According to the Glass Company, these cullet usage barriers do exist due to the contaminations or quality problems of raw cullet.

According to the financial analysis carried out for different scenarios, introducing door to door collectors was selected as the best scenario due to highest net profit yielded per year. In Sri Lanka, the responsibility

for the glass waste collection and introduction of door to door collection systems are required focus in the future. Presently local authorities practice door to door collection in selected areas. Some local authorities provide with three colour bags for households in order to encourage them for separation of recyclable waste as paper and cardboard, plastic and polythene and glass wastes. Monetary and technical assistance are provided by Central Environmental Authority (CEA) and Waste Management Authority (WMA) for the establishment of collection centers for recyclable wastes in different areas.

Therefore most suitable method for the implementation of door to door collection is through establishment of collection centers in every region of the country. At the initial stage when initializing these activities, financial and labour requirements will be high. Regional collectors can collect glass waste from houses, retailers, super markets and companies. A proper time schedule should be prepared in order to visit one house at least once a month. Monthly collections of all regions in a particular district can be sold to the Glass Company in a selected day. Even though this method creates lot of additional costs, it will be beneficial for the country since more economic and environmental benefits could have been generated. From country point of view it generates more employment opportunities, reduces glass waste

\section{REFERENCES}

Agarwal, T.L., 2008. Reduce, reuse, recycle, Pearson education, Dorling Kindersley (India) Pvt Ltd; pp 12,13,32. Annual reports of Piramal Glass Ceylon PLC in 2008 and 2009.

Proceedings of the 15 ${ }^{\text {th }}$ International Forestry and Environment Symposium, 26-27 November 2010.

Published by Department of Forestry and Environmental Science, University of Sri Jayewardenepura, Sri Lanka. 
Bandara, N.J.G.J., 2004. Municipal Solid Waste Management, The Sri lankan case, Silver Jubilee, 2008, Department of Forestry and Environmental Science, University of Sri Jayewardenepura; pp 72-80.

Bogert, S. and Morris, J., 1993. The economics of recycling.

Bolaane, B., 2005. Constraints to promoting people centered approaches in recycling; pp 1-9.

Butler, J. and Hooper, P., 2005. Dilemmas in optimizing the environmental benefit from recycling: A case study of glass container waste management in the UK; pp 331-353.

Database of Municipal Solid waste in Sri Lanka, January 2005, Ministry of Environment and Natural resources.

Energy implications of glass container recycling, recycling coordinator, 1995.

Fix, A. 2008. Reduce, reuse, recycle, Pearson education Ltd.

Krivtsov,V., Wager, P.A., Dacombe, P., Gilgen, P.W., Heaven, S., Hilty, L.M. and Banks, C.J., 2004. Analysis of energy footprints associated with recycling of glass and plastic-case studiesfor industrial ecology; pp 175-188.

Local government recycling cooperative and act packaging 1997, recycle 2000, fact sheet.

Martin, M., Williams, I.D., and Clark,. M., 2005. Social, cultural and structural influences on household waste recycling: A case study; pp 1-37.

Robinson, G.M. and Read,. A.D., 2005. Recycling behavior in a London Borough: Results from large-scale household surveys; pp 70-82.

Sidique, S.F., Lupi, F. and Joshi, S.V., 2009. The effect of behavior and attitudes on drop-off recycling activities; pp $1-7$.

Sri Lanka Customs data base, 2009.

Tietenberg, T. and Lewis, T., 2009. Environmental and Natural resource Economics, $8^{\text {th }}$ edition; pp 192-213.

Timlett, R.E. and Williams, I.D., 2007. Public participation and recycling performance in England: A comparison of tools for behavior change; pp 622-632.

United States environmental protection agency, Markets for recovered glass, 1992.

Vellini, M. and Savioli, M., 2008. Energy and environmental analysis of glass container production and recycling, pp 1-7.

Boteju, N. Finance Controller, personal communication, (2009), Glass Company.

Dharmasena, C.D.L. Asst. Purchasing Manager, personal communication, (2009), Glass Company.

Gunasiri, T. Asst. Manager Finance, personal communication, (2009), Glass Company.

Liyanaarachchi, K.A.P.H. Registrar of mineral titling, personal communication, (2010), GSMB.

Perera, K.S.C. Asst. Manager- Cold End, personal communication, (2009), Glass Company.

www.piramalglassceylon.com accessed on 02/10/2009.

Proceedings of the 15 ${ }^{\text {th }}$ International Forestry and Environment Symposium, 26-27 November 2010.

Published by Department of Forestry and Environmental Science, University of Sri Jayewardenepura, Sri Lanka. 